\title{
INTERPRETATION OF THE SIGNS IN THE TRADITION OF MA'BACA-BACA AMONG THE MUSLIM SOCIETY OF BUGIS BONE
}

\author{
Agustina Riska Eka Saputri ${ }^{1}$, Dadan Rusmana ${ }^{2}$ \\ ${ }^{1,2}$ English Literature, Faculty of Adab and Humanities, State Islamic University of Sunan Gunung Djati, \\ Bandung \\ e-mail: 'agustinariskaekasaputri@gmail.com, ${ }^{2}$ dadan.rusmana@uinsgd.ac.id
}

\begin{tabular}{|c|c|}
\hline Article Info & Abstract \\
\hline $\begin{array}{l}\text { Keyword: } \\
\text { Ma'baca-baca; } \\
\text { Meaning; } \\
\text { Signs. }\end{array}$ & $\begin{array}{l}\text { This research aims to explain the signs and their meaning in Ma'baca- } \\
\text { baca tradition among Bugis Bone Muslim society. The research } \\
\text { problems consist of } 1 \text { ) What are the signs found in the tradition of } \\
\text { Ma'baca-baca among Bugis Bone Muslim society; 2) What is the } \\
\text { meaning of the signs that exist in the tradition of Ma'baca-baca among } \\
\text { the Muslim society of Bugis Bone. The research used Charles Sanders } \\
\text { Peirce's semiotic theory to analyze these problems, which involves a } \\
\text { triangle theory of meaning, linking, and three main elements - } \\
\text { representamen (sign), object, and interpretant. In addition, Bronislaw } \\
\text { Malinowski's theory of cultural functionalism was used to interpret the } \\
\text { data. The research method used is a qualitative descriptive method: } \\
\text { observation, interviews, and documentation. This study resulted in the } \\
\text { following conclusions: 1) There are } 5 \text { verbal signs and } 18 \text { nonverbal } \\
\text { signs in the tradition of } M a^{\prime} b a c a-b a c a \text { among Bugis Bone Muslim } \\
\text { society, 2) All signs contained in Ma'baca-baca tradition have their } \\
\text { meanings that are interpreted and believed by the local society. }\end{array}$ \\
\hline Article Info & Abstrak \\
\hline $\begin{array}{l}\text { Kata Kunci: } \\
\text { Ma'baca-baca; } \\
\text { Makna; } \\
\text { Tanda. }\end{array}$ & $\begin{array}{l}\text { Penelitian ini bertujuan untuk menjelaskan tanda (signs) dan } \\
\text { maknanya dalam tradisi Ma'baca-baca di kalangan masyarakat Muslim } \\
\text { Bugis Bone. Rumusan masalah penelitian terdiri dari 1) Apa saja tanda } \\
\text { yang ditemukan dalam tradisi Ma'baca-baca di kalangan masyarakat } \\
\text { Muslim Bugis Bone; 2) Apa makna tanda yang ada dalam tradisi } \\
\text { Ma'baca-baca di kalangan masyarakat muslim Bugis Bone. Penelitian } \\
\text { ini menggunakan teori semiotika Charles Sanders Peirce untuk } \\
\text { menganalisis permasalahan, yang melibatkan teori segitiga makna, } \\
\text { keterkaitan, dan tiga elemen utama-representamen (tanda), objek, dan } \\
\text { interpretant. Selain itu, teori fungsionalisme budaya Bronislaw } \\
\text { Malinowski digunakan untuk menginterpretasikan data. Metode } \\
\text { penelitian yang digunakan adalah metode deskriptif kualitatif: } \\
\text { observasi, wawancara, dan dokumentasi. Penelitian ini menghasilkan } \\
\text { kesimpulan sebagai berikut: 1) Terdapat } 5 \text { tanda verbal dan } 18 \text { tanda } \\
\text { nonverbal dalam tradisi Ma'baca-baca di kalangan masyarakat Muslim } \\
\text { Bugis Bone, 2) Semua tanda yang terkandung dalam tradisi Ma'baca- } \\
\text { baca memiliki makna yang ditafsirkan dan diyakini oleh masyarakat } \\
\text { setempat. }\end{array}$ \\
\hline
\end{tabular}

\section{Introduction}

According to Press Release of the Ministry of Education and Culture No:137/sipres/A6/VI/2020, Indonesia consists of diverse tribes, religions, languages, and cultures. Each region in Indonesia has its own uniqueness and traditional pattern. The diversity of traditions in Indonesia urges people to maintain and preserve these traditions. Discussing the traditions that exist 
in Indonesia indeed cannot be separated from the previous human civilization or its ancestors that contain norms and values that are very dependent on the people who adhere to these traditions. We can see one of them in the Bugis people in South Sulawesi, who are known to be rich in culture and traditions that are practiced for generations. Tradition is a cultural heritage or past custom that continues to be preserved to this day. According to the understanding of previous traditions, a continuously practiced culture is called tradition (Rodin, 2013). Tradition is considered a tribute to ancestors' spirit, gratitude to God, a means of socialization, and affirmation of cultural values that already exist and are applied by the community (Andriyanti, Haerudin, \& Kosasih, 2019). In the simplest definition, tradition is something that has lived on for a long time and belongs to the lives of a group of people who usually come from the same country, culture, time, or religion. The simplest thing about tradition is that information is passed down from generation to generation, both in writing and orally, because tradition can be destroyed without it (Margahana \& Triyanto, 2019). Traditions closely related to character and geographical conditions (Muhakamurrohman, 2014). Tradition is part of a culture resulting from human creation, taste, and human initiative. Culture cannot be separated from society because it regulates many things and is related to the values that guide life. The cultural system is like a living thing with interdependence, and each part has a relationship. To maintain its existence, each cultural system has certain conditions and functions (Prayetno \& Qomaruzzaman, 2021). The current development certainly impacts ancestral traditions that are loaded with traditional rituals. Some are preserved, but many are missing. It is undoubtedly homework for the younger generation as a mouthpiece for the next generation. Ritual communication is a communication function used to fulfill human identity as an individual, a member of a social society, and an element of the universe. Ritual communication is closely related to the emotional bond between individuals and society (Rusnali \& Syam, 2021). Many signs contain messages and teachings of kindness that want to be conveyed in a traditional ritual. Rituals show the order of the objected symbols. These symbols express behaviors and feelings and form devotees' personal dispositions who follow their respective models. Each ritual carried out consists of many symbols that have their own meaning (Kusuma \& Nurhayati, 2017).

There are two important signs that represent human identity: verbal and nonverbal. Both as a form of unity between humans and their environment and aim to communicate or interact socially. Verbal signs consist of two forms, namely oral and written (Masreng, 2016). One of the traditions that still exist in South Sulawesi and survives is the tradition of Ma'baca-baca among the Muslim society of Bugis Bone. This tradition is often encountered in various regions; although the name is different, the goal is the same, namely gratitude to Allah SWT. For the favors that have been given, some aim to reject reinforcements and many other purposes. Each tribe or region has a different method of execution, each with its own method and uniqueness. (Arifin \& Rahman, 2019). The tradition of Ma'baca-baca is derived from Bugis Bone language "ma'baca" which means reading. In this case, the tradition of Ma'baca-baca can be interpreted as the process of reading or praying. However, this tradition of $M a^{\prime}$ baca-baca is different from reading prayers in general, because it is only carried out at a particular time, for example, before fasting, before eid, after eid, after the rice harvest, or when fulfilling vows, for example, vows if the child graduates from college. The prayer was recited by pabbaca (a person trusted by the public to recite the prayer). Pabbaca is usually an $u s t a d z$, imam of the mosque, the elder, or a respected person in the neighborhood who understands the prayers (Hamzah, 2021). In this procession of Ma'baca-baca, the person who held the event or asked to be prayed for will serve various kinds of food in front of the pabbaca, which has its own meaning. Then, the food is given to guests, families, and neighbors.

Therefore, in this study, the researchers tried to discuss more specifically and describe the interpretation of signs in the tradition of Ma'baca-baca conducted by the Muslim society of Bugis Bone. Researchers hope to share insights and inspiration widely related to culture that is of particular concern to the public. This research aims to explain the signs contained in the tradition of $\mathrm{Ma}^{\prime} \mathrm{baca}$ baca among Bugis Bone Muslim society and the meaning of these signs. It encourages researchers to 
conduct research on the interpretation of signs on the tradition of Ma'baca-baca among the Muslim society of Bugis Bone. The article discusses the signs and their meaning found in the tradition of Mabaca-baca,

\section{Methodology}

The research method used in this research is qualitative descriptive. The research produced descriptive data in information from people who are believed to know the observed behavior and objects. The research on the tradition of Ma'baca-baca was conducted in Tanete Village, Cina Subdistrict, Bone Regency, South Sulawesi Province. This research used Charles Sanders Peirce's semiotic theory. This theory is trichotomous, namely proposing the triangle meaning theory, linking the three facets that become the main elements, which are representamen (sign), object, and interpretant (Rorong, 2019), and assisted by Bronislaw Malinowski's theory of cultural functionalism which explains that all elements of culture are a valuable part of the society in which these elements exist.

\section{Discussions}

Society welcomes the existence of Islam in Indonesia because of the ability of ulema to acculturate Islamic cultures into local belief cultures. In the context of the spread of Islam in Indonesia, especially in South Sulawesi, traditions that are part of society's culture are carefully, intelligently, and proportionately. Islamic religious preaching uses the media of tradition as one of the strategies in grounding Islamic teachings by using various approaches according to people's habits. By going through the process of assimilation and cultural acculturation, Islam in South Sulawesi can develop without eliminating the values of local traditions and even giving Islamic contents to the values of existing traditions and enriching their meaning in society. The existence of Islam in Bugis society is a form of acceptance of new values into established cultures. With the continuity of customs and Islam, in various activities of life, religious activities are always accompanied by spirituality produced by wisdom brought by customs (Wekke, 2013). It can be seen from the Muslim society of Bugis Bone in Ma'baca-baca. According to the Muslim society of Bugis Bone, Ma'baca-baca tradition is allowed, and even the previous preachers of Islam continue to carry it out for generations. Until now, it is still practiced in the Muslim society of Bugis Bone and maintained its sustainability.

Ma'baca-baca is an attempt of Bugis Bone Muslim society to present religious figures or indigenous figures to recite specific prayers to avoid bad things, to express gratitude for everything a person get, or to pray for the late family members. Ma'baca-baca is done at the house of the person who intends to pray. The host prepares the offerings that have been made, including lighting incense sticks. Pabbaca then recited prayers in front of the meal. The procession continued with eating together and then distributing the food to family and neighbors. It symbolizes caring and harmony between communities.

The Semiotic theory of Charles Sanders Peirce has three main elements. First, a sign, commonly called representment, can represent something for the function of something. Representment representation is the physical form or everything that can be absorbed by the senses and refers to something. Researchers used signs in the form of documentation of signs used in the tradition of Ma'baca-baca. Then, an object refers to a sign, something represented by a sign related to reference, while interpretant is the meaning in a person's mind about the object referred to as the sign.

From the results of interviews conducted by researchers, there are several signs mentioned and explained by the source. The researchers further classified it based on the semiotic analysis of Charles Sanders Peirce, namely as follows:

\section{Verbal Signs}


Verbal signs are words and other linguistic structures, such as phrases, clauses, and others (Sunjaya \& Irmayanti, 2021). When a group is formed, the meaning of symbols and rules appears and is done through interaction. From these interactions, the symbols are used and interpreted by group members. We can communicate with others because there is shared meaning. The same meaning is only formed when we have the same experience or similar cognitive structure. Symbols require a more intensive process of meaning after being connected to an object. As understood in a cultural context, language is influential in human culture. Without language, culture and anything else in the world cannot develop properly. It can even be said that all activities in life would not exist without language. Therefore, language is the result of human culture that is very important in building world civilization in the past, present, and future (Debyani, 2019). In the tradition of Ma'baca-baca, there are verbal signs or spoken language in the form of mantras and prayers spoken, including the following:

Table 1. Verbal signs in the tradition of Ma'baca-baca among the Muslim society of Bugis Bone

\begin{tabular}{|c|c|c|c|}
\hline No. & Representamen & Object & Interpretant \\
\hline 1. & $\begin{array}{l}\text { Mallaleng asengmu api, } \\
\text { pappalettu iko asengmu dupae, } \\
\text { pulettukang'nga ri Nabitta', } \\
\text { Nabitta'pa palettu risininna tao } \\
\text { laoku yamaneng. }\end{array}$ & Incense mantra & $\begin{array}{l}\text { It is meant as a form of respect for the } \\
\text { Prophet Muhammad SAW. before } \\
\text { beginning to recite prayers. }\end{array}$ \\
\hline 2. & $\begin{array}{l}\text { Uniakang'i kiringang fatehah } \\
\text { pangelukku Muhammad SAW. } \\
\text { Ilaa hadhratin nabiyyil } \\
\text { mushthafaa muhammadin } \\
\text { shallallaahu 'alaihi wasallam. } \\
\text { Al-Fatihah... (Reciting surah } \\
\text { Al-Fatihah) }\end{array}$ & $\begin{array}{l}\text { The intention of } \\
\text { sending Al- } \\
\text { Fatihah to the } \\
\text { Prophet } \\
\text { Muhammad } \\
\text { SAW. }\end{array}$ & $\begin{array}{l}\text { The intention of sending Al-Fatihah } \\
\text { to the Prophet Muhammad SAW is } \\
\text { interpreted as giving respect and } \\
\text { asking for blessing to get what we } \\
\text { want. }\end{array}$ \\
\hline 3. & $\begin{array}{l}\text { Upakaraja sukkurukku lao } \\
\text { ripuang Allah ta'ala, Puang } \\
\text { yamabbere dalle, nennia umuru } \\
\text { malampe. }\end{array}$ & $\begin{array}{l}\text { The prayer of } \\
\text { gratitude to Allah } \\
\text { SWT. }\end{array}$ & $\begin{array}{l}\text { The prayer of gratitude to Allah SWT. } \\
\text { is interpreted as surrender to Allah } \\
\text { SWT. and as a gratitude for the wealth } \\
\text { and life given by Allah SWT. }\end{array}$ \\
\hline 4. & $\begin{array}{l}\text { O puang Allah taala, puang } \\
\text { marajae, } \\
\text { namiakang' } i \\
\text { asalamakeng ri dunia nennia } \\
\text { akhera'... (Mention the name } \\
\text { of the person who asked to be } \\
\text { prayed for) nennia sininna } \\
\text { silessurengna. }\end{array}$ & $\begin{array}{l}\text { Prayer asking for } \\
\text { salvation for the } \\
\text { person carrying } \\
\text { out } M a^{\prime} \text { baca-baca } \\
\text { and his/her family. }\end{array}$ & $\begin{array}{l}\text { This prayer is interpreted as a request } \\
\text { to Allah SWT. so that people carrying } \\
\text { out the tradition of Ma'baca-baca are } \\
\text { given the salvation of the world and } \\
\text { the hereafter. }\end{array}$ \\
\hline 5. & $\begin{array}{l}\text { O puang Allah taala, puang } \\
\text { marajae, tulakang'i sininna } \\
\text { abala'e keluargana... (Mention } \\
\text { the name of the person who } \\
\text { asked to be prayed for) nennia } \\
\text { sininna silessurengna. }\end{array}$ & $\begin{array}{l}\text { Prayer to be kept } \\
\text { away from all } \\
\text { dangers/ avoid } \\
\text { bad things. }\end{array}$ & $\begin{array}{l}\text { This prayer is interpreted as a request } \\
\text { to Allah SWT. to be kept away from } \\
\text { all dangers/ avoid bad things for } \\
\text { families carrying out Ma'baca-baca. }\end{array}$ \\
\hline
\end{tabular}

Mantras and prayers recited in the ma'baca-baca tradition are nonverbal signs. The discussion is as follows: 
1) Mallaleng asengmu api, pappalettu iko asengmu dupae, pulettukang'nga ri Nabitta',

Nabitta'pa palettu risininna tao laoku yamaneng.

(Walking is your name fire,

The messenger is your name incense,

Tell the Prophet,

The Prophet who delivered the message to everyone has died and gone before us)

Bugis Bone Muslim community uses the mantra to put incense before the pabbaca begins to recite the prayer, and the content of the mantra is a representamen. The object is the incense mantra. People interpret it as a form of respect for the Prophet Muhammad SAW.

2) Uniakang'i kiringang fatehah pangelukku Muhammad SAW.

(I intend to send Al-Fatihah to the Prophet Muhammad Saw.)

Ilaa hadhratin nabiyyil mushthafaa muhammadin shallallaahu 'alaihi wasallam. Al-Fatihah... (Reciting surah Al-Fatihah)

Before reciting the prayer, the pabbaca first recited the intention and sent Al-Fatihah to the Prophet Muhammad SAW. The content of intention is representamen, and the intention of sending Al-Fatihah to the Prophet Muhammad is the object. The society interprets it as respect and asking for the blessing.

3) Upakaraja sukkurukku lao ripuang Allah ta'ala, Puang yamabbere dalle, nennia umuru malampe.

(Praise and thanks to Allah Swt., God is the giver of sustenance and long life.)

The content of this prayer is a representamen, and the object is the prayer of gratitude to Allah SWT. People interpret it as surrender to Allah SWT. and express gratitude for the sustenance and long life given by Allah SWT.

4) O puang Allah taala, puang marajae, uniakang'i namamoare diareng'i asalamakeng ri dunia nennia akhera'... (Mention the name of the person who asked to be prayed for) nennia sininna silessurengna.

(O Allah, the Lord, grant salvation both in this world and in the hereafter ... and his/her family)

The content of the prayer is representamen, and the prayer is the object. It means a request to Allah SWT. so that people carrying out Ma'baca-baca tradition are given salvation in the world and hereafter.

5) O puang Allah taala, puang marajae, tulakang'i sininna abala'e keluargana... (Mention the name of the person who asked to be prayed for) nennia sininna silessurengna.

(O Allah, the king, keep away .... and his family from all calamities and problems) 
The content of the prayer is representamen, and the object is prayer to be kept away from all dangers/ avoid bad things. People interpret it as a request to Allah SWT. to be kept away from all dangers/ avoid bad things for families who carry out the tradition of ma'baca-baca.

\section{Nonverbal Signs}

In terms of applying semiotics to nonverbal signs, the main thing to note is the understanding of the nonverbal field. The nonverbal field is a region that emphasizes the importance of phenomena that are empirical, factual, or concrete, without language speech. It means the nonverbal field is related to concrete, real, and demonstrable objects through the human senses (Susanti \& Asyari, 2017). The types of messages formed by nonverbal signs always have connotations because of the social value (Rakhmat \& Fatimah, 2016). Here are the nonverbal signs found in the tradition of ma'baca-baca:

Table 2. Nonverbal signs in the tradition of ma'baca-baca among the Muslim society of Bugis Bone

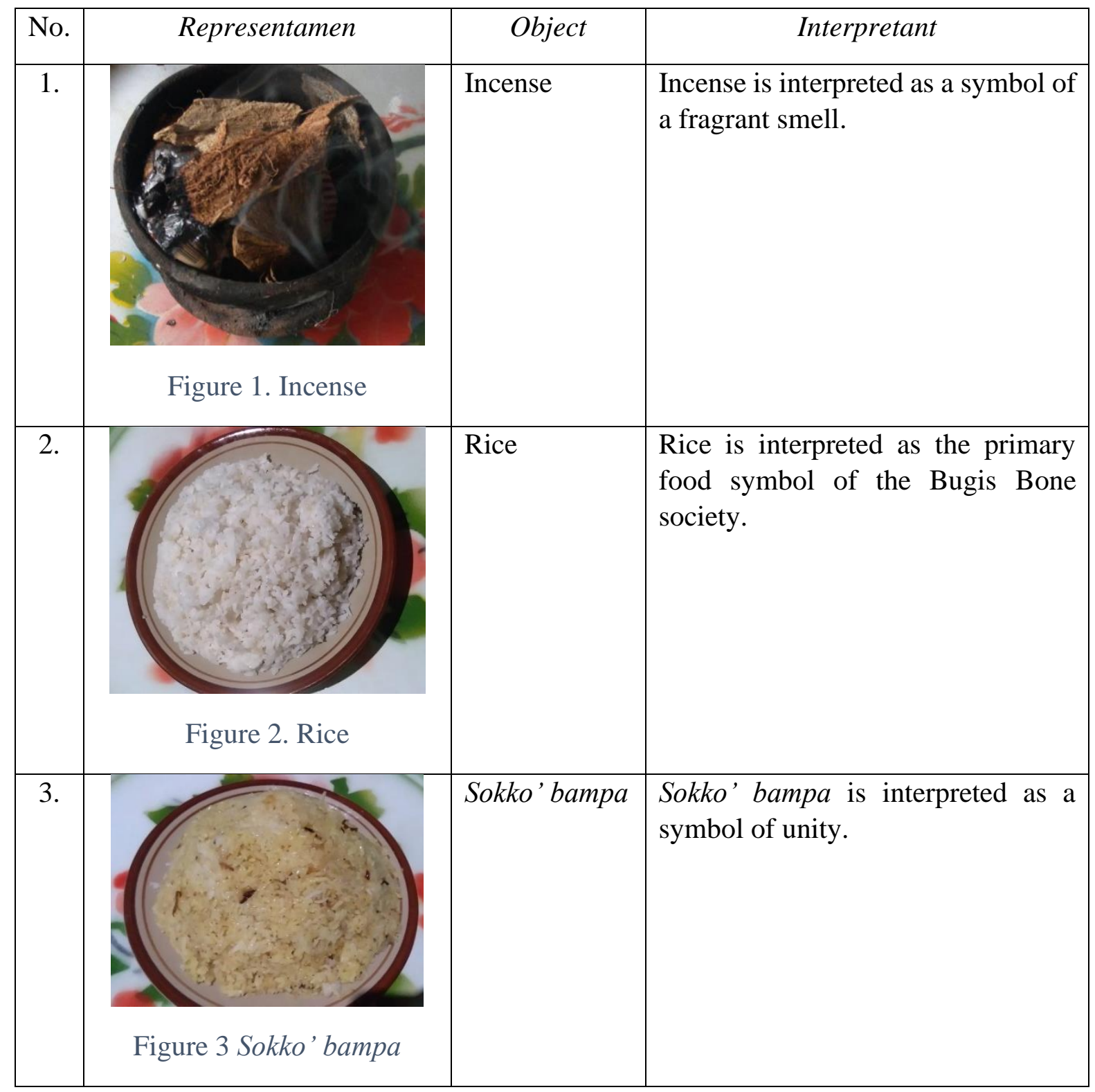




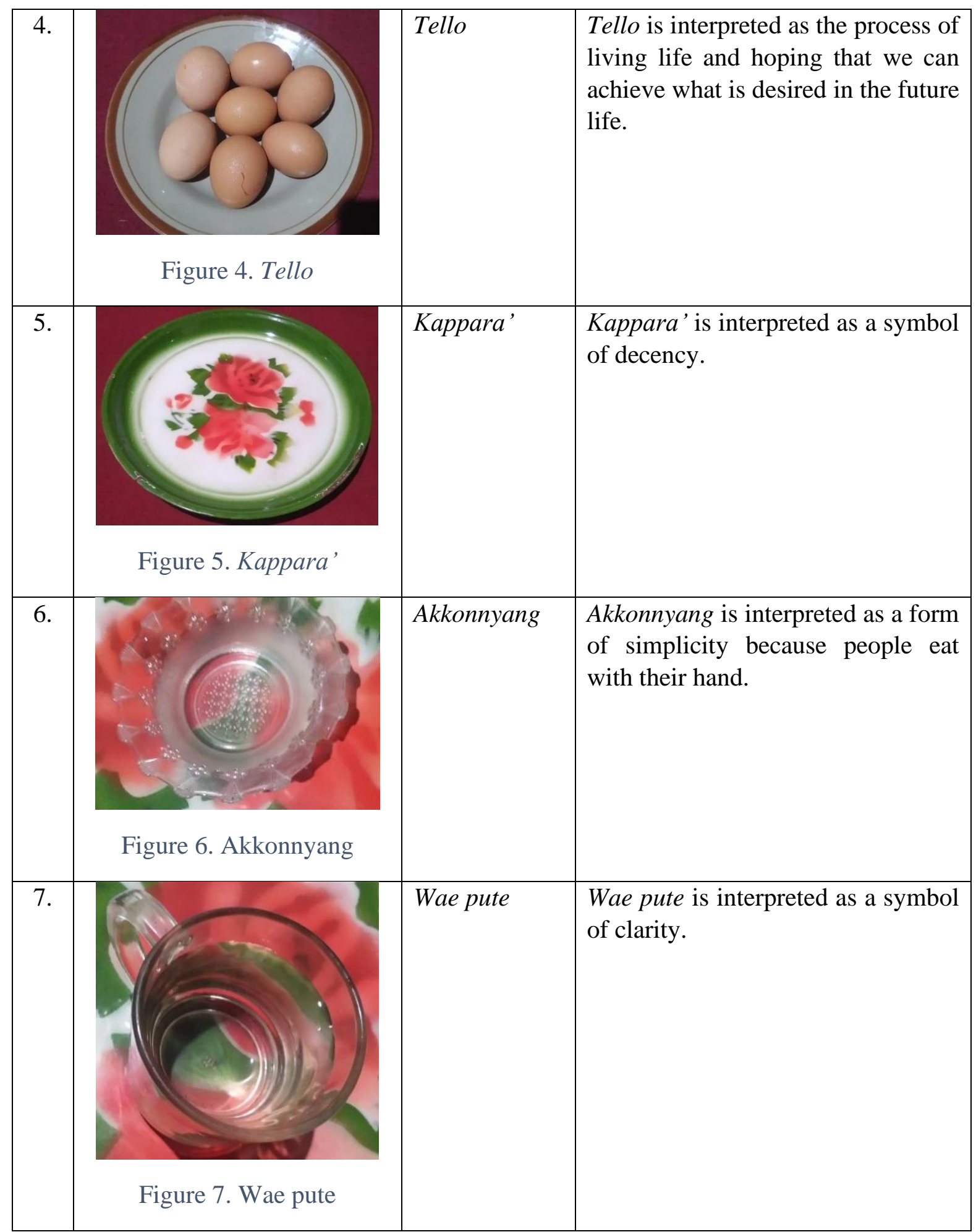




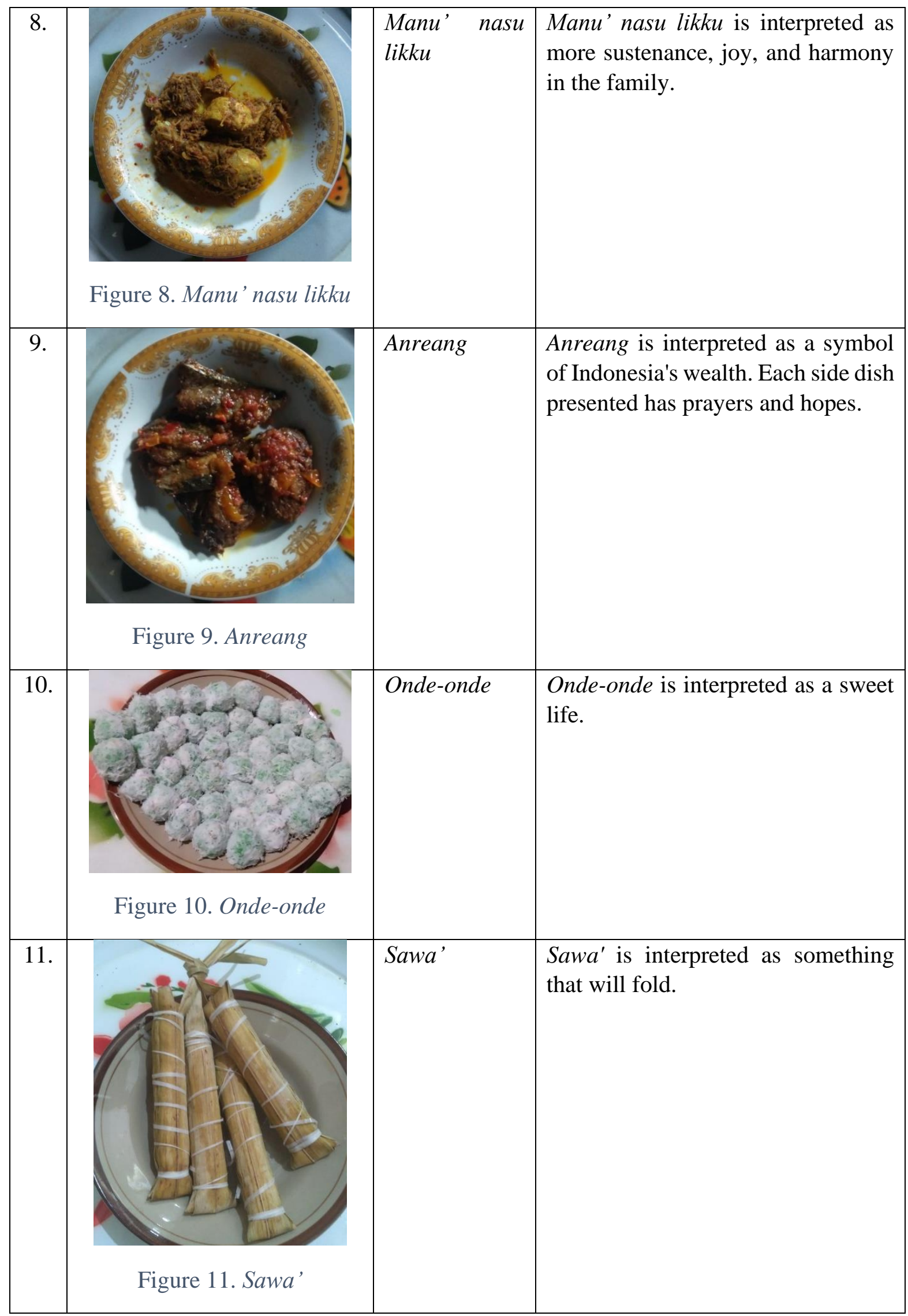




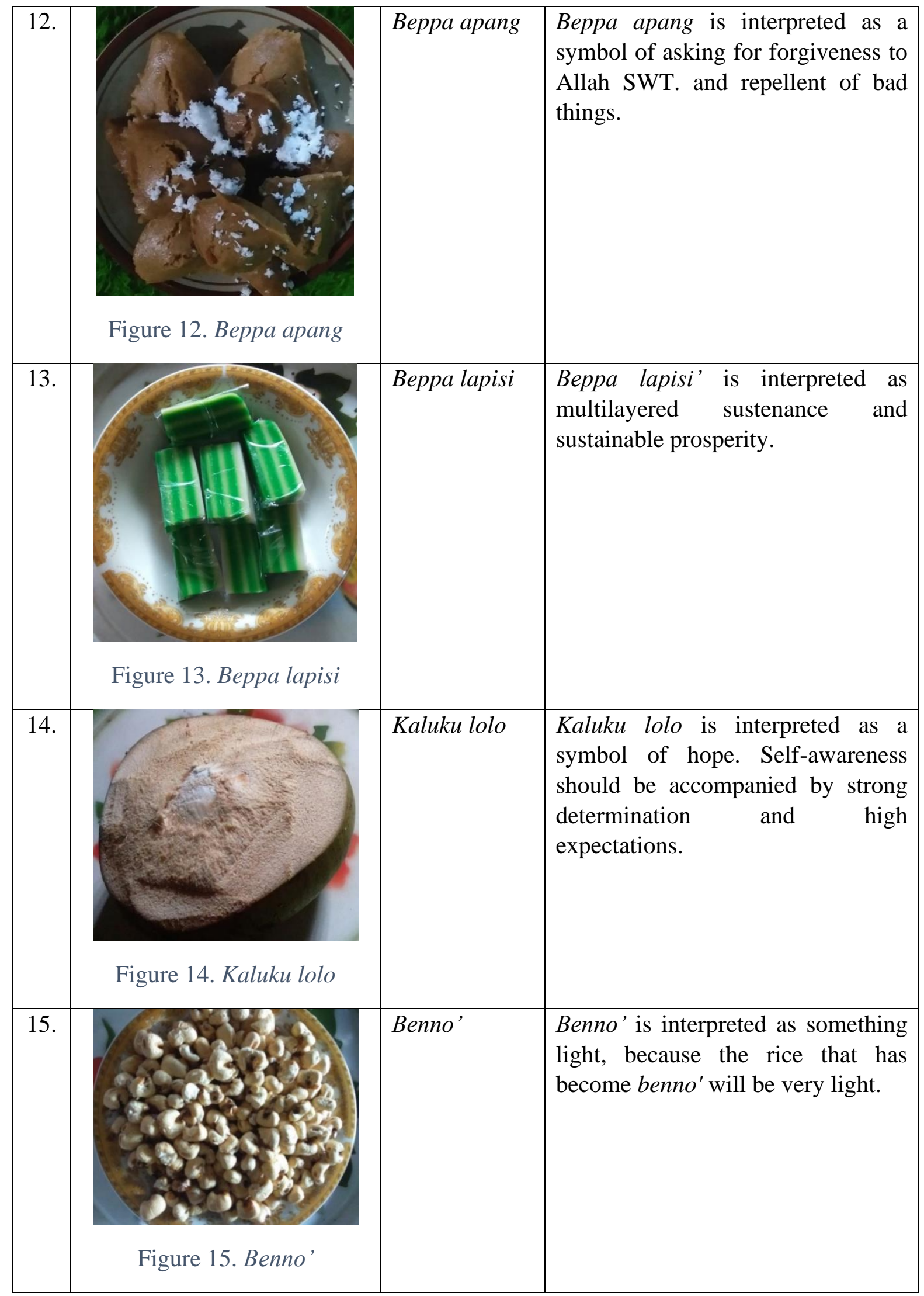




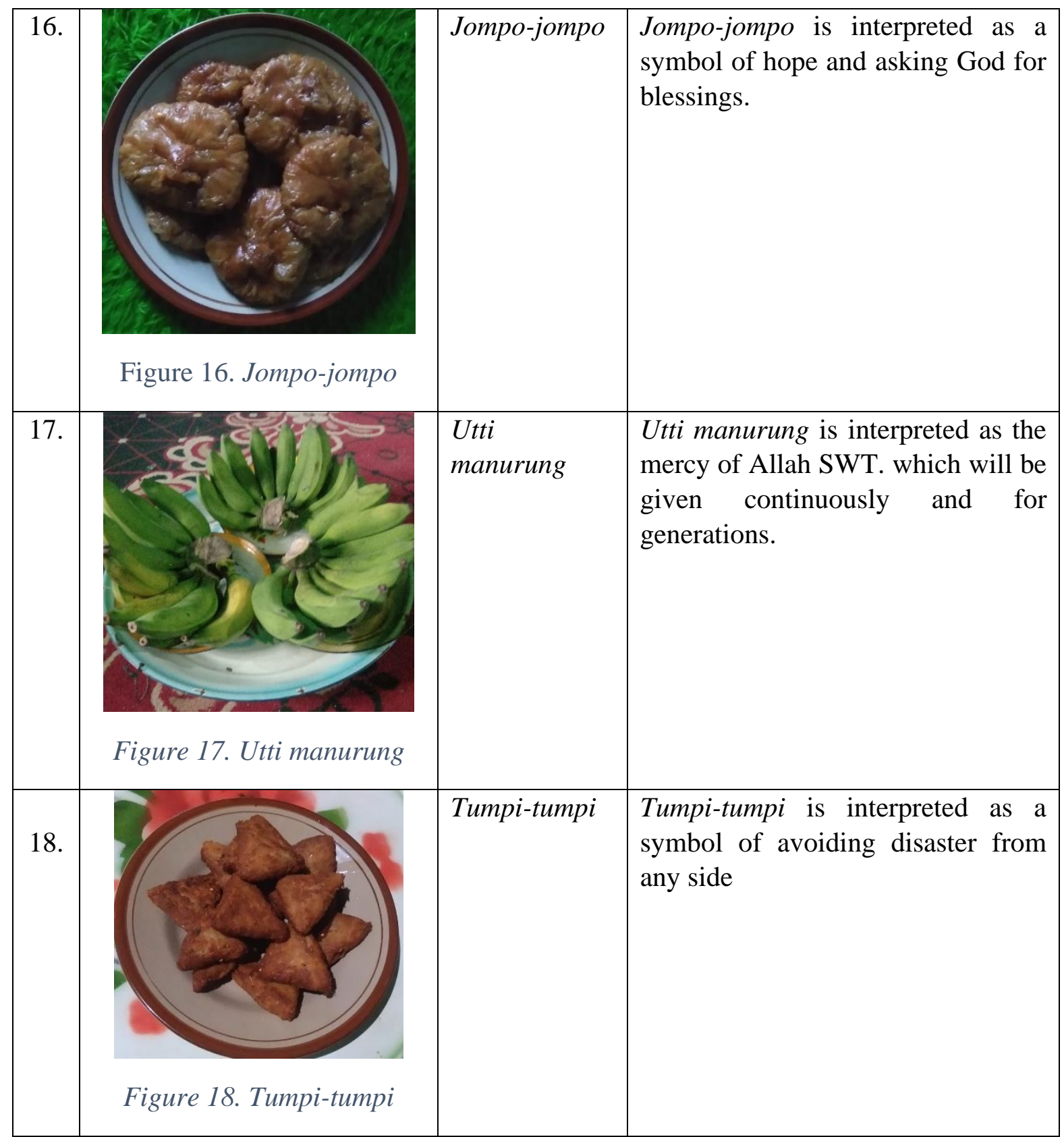

The discussion of verbal signs contained in the tradition of ma'baca-baca is as follows:

1) The picture of incense is a sign because it can physically represent the senses. The object is incense, a material that will produce a fragrant smell when burned. It makes people interpret incense as a symbol of a fragrant smell. Initially, incense was mandatory in the tradition of Ma'baca-baca. The fragrant smell of incense has the meaning of bringing life to the life of the person who performs the tradition of Ma'baca-baca.

2) The rice picture is part of the signs in the tradition of $M a^{\prime}$ baca-baca. The object is the rice itself. Rice is interpreted as the main food symbol of the Bugis Bone society.

3) The picture of sokko' bampa is a sign, and the object is sokko' bampa, food made from glutinous rice steamed to ripen. Sokko' bampa is a food that is mostly present in the tradition of Bugis society, including Ma'baca-baca tradition. Sokko' bampa has a very sticky texture. It makes society interpret it as a union. In this tradition, we can see the unity of society. They still carry out this Ma'baca-baca tradition to this day. They believe the meaning of unity in sokko' bampa, will make them always united, create friendship and help each other. 
4) The tello' picture is a representamen or sign of Ma'baca-baca tradition, and the object is tello' or boiled egg. Boiled egg is interpreted as the process of living life and hoping that future life can achieve what is desired.

5) The picture of kappara' is one of the nonverbal signs in Ma'baca-baca tradition. Kappara' is a large tray made of brass iron and have a round shape. The device used as a container of the food provided is the object of the sign. Kappara' is interpreted as a symbol of decency, glorifying the person served.

6) The picture of akkonnyang is a sign and the object is akkonnyang. Akkonnyang is a small bowl filled with water used to wash fingers before and after meals. Akkonnyang is interpreted by society as a form of simplicity because people eat using their hands.

7) The picture of wae pute is a sign of the Ma'baca-baca tradition. The object is wae pute or water that has been cooked and ready to drink. Water is a necessity in all traditions of Ma'baca-baca, because whatever food is served, it requires water to drink. So, water is interpreted as a symbol of clarity, which is to clear the person's life who carries out the tradition of Ma'baca-baca. When a person works, that person needs drinking water to refresh the throat.

8) The picture of manu' nasu likku is a representamen, and the object is manu'nasu likku. Manu' nasu likku is chicken cooked with grated galangal or roughly chopped. Manu' nasu likku is interpreted as more sustenance, joy, and harmony in the family.

9) The picture of anreang is a representamen, and the object is anreang. Anreang is interpreted as a symbol of Indonesia's wealth. Each side dish presented has prayers and hopes.

10) The picture of onde-onde is one of the signs of the ma'baca-baca tradition. It has been explained that the representamen used by researchers are things that can physically represent the senses, and researchers using pictures. The object is onde-onde, a cake made from glutinous rice flour shaped like small balls, then filled with a mixture of coconut and sugar boiled in boiling water and served with grated coconut wrap. From the explanation of the object, onde-onde is interpreted to have two meanings, namely symbolizing a sweet life because of its taste and rolling the impending disaster because of its round shape. Onde-onde is usually presented at the Ma'baca-baca event to reject the reinforcements.

11) The picture of $s a w a$ ' is a representamen or sign. The object is sawa', food made from glutinous rice then wrapped in coconut leaves. Sawa' also known as leppe-leppe' because of its folded shape. Sawa' has a shape that multiplies so that the society interprets it will fold the calamity that will occur and multiply the windfall of people who carry out the tradition of Ma'baca-baca.

12) The image of beppa apang is a representation, while the object is beppa apang or apang cake, a cake made from rice flour and palm sugar, steamed using a mold served with coconut grater. Beppa apang is interpreted to have the meaning of "ta ngapa-ngapa" and a symbol of blessing. "Ta ngapa-ngapa" means it's okay. It means that when the event owner has an accident, there are no severe injuries. The symbol of blessing itself is seen in the process of making it. The cake mold is only filled in half, but it will spread to the entire mold. Beppa apang is also commonly served at massuro mabbaca events to reject reinforcements.

13) The picture of beppa lapisi is a representamen or sign. Beppa lapisi is a layer cake made from rice flour and starch, which is then colored and made in layers. This cake is the object of the sign itself. Layer cake consists of layers. This cake is the object of the sign itself. Layer cakes with a multilayered shape symbolized effort, so that the windfall happening to people who carry out the event will be layered if they have prayed and tried.

14) The picture of kaluku lolo is a representamen, and the object is kaluku lolo. Kaluku lolo is a young coconut that is interpreted as a symbol of hope. Self-reflection should be accompanied by strong determination and high expectations.

15) The picture of benno' is the sign and benno' is the object. Rice that is roasted using a furnace. Rice is roasted until the skins of the rice are detached and become benno'. Heavy rice will turn light when finished roasting. That is what benno' means, making heavy work light. 
16) The picture of Jompo-jompo is representamen. The object is jompo'jompo. Jompo-jompo' is cake made from rice flour, wheat flour, brown sugar, and coconut water. The round shape and reddish color are taken from the word 'mompo' which means to appear, hoping that everything that appears is always good and a symbol of a request for blessings to God.

17) The picture of utti manurung is a sign or representamen. The object is utti manurung. Utti manurung is a banana that has a sweet taste, and its tender texture makes this banana processed by many people. Society interprets utti manurung as a symbol of sustenance for generations and continuously.

18) The picture of tumpi-tumpi is a representamen, and the object is tumpi-tumpi. Tumpi-tumpi is a triangular-shaped food made from flour and tuna meat. Tuna is steamed with grated coconut, lemongrass, shallots, chili, and lime. Because it has a triangular shape, it can be interpreted as preventing disaster from all directions.

The interpretation of signs, according to Peirce provides the knowledge that interpretants influence our behavior in certain situations. It can be seen in the interpretation of the sign of the Ma'baca-baca tradition, making people perform the tradition with hope in accordance with the meaning of the sign that the Muslim society has believed of Bugis Bone.

The sign process, objects and interpretants called semiosis occurs very quickly in human thought, because the real thing in the senses is representamen. Peirce sees semiosis as a process that continues without end. He believes interpretant can be captured by the mind and seen as a new sign, namely the new representative. According to Peirce, a sign is an open work. It means that every sign, which is part of the culture of a society, is always open to experiencing an infinite process of semiosis. A sign can be understood and interpreted differently at different places and times or even by the same person at different places and times. So, do not rule out the possibility that the tradition of Ma'baca-baca has different meanings in each region that performs the tradition.

Based on the theory of cultural functionalism from Bronislaw Malinowski, in the implementation of the Ma'baca-baca tradition there are benefits and values in it. The values contained in the tradition of Ma'baca-baca, among others, are the value of faith, the value of worship, social values, cultural values, and philosophical values. From the values in the tradition of Ma'baca-baca among Bugis Bone Muslim society can be taken wisdom and positive side and good habits that can be passed on to future generations. It serves as a guide to creating religious harmony, peace, and prosperity that is prosperous and happy in social life.

\section{Conclusions}

Each region in Indonesia has its own uniqueness and traditional pattern. One of them is in the Bugis Muslim society in Tanete Village, Cina Subdistrict, Bone Regency, South Sulawesi, which still carries out the tradition of Ma'baca-baca. This tradition of ma'baca-baca is interpreted as a process of reading or praying, recited by "pabbaca". This tradition aims to express gratitude to Allah SWT. or as a repellent. In this tradition of praying, there are verbal and nonverbal signs. Objects of verbal sign in the tradition of ma'baca-baca among the Muslim society of Bugis Bone including, incense prayer, the intention of sending Al-Fatihah to the Prophet Muhammad SAW., the prayer to thank Allah Swt, ask for salvation for the person carrying out Ma'baca-baca, and avoid bad things. The objects in nonverbal signs in Ma'baca-baca among Bugis Bone Muslim society consist of incense, rice, sokko' bampa, tello, kappara', akkonnyang, wae pute, manu' nasu likku, anreang, onde-onde, sawa', beppa apang, beppa lapisi, kaluku lolo, benno', jompo-jompo, utti manurung, tumpi-tumpi. All signs in the tradition of Ma'baca-baca have their own meanings interpreted and believed by the local society. There are benefits and values in Ma'baca-baca: faith, the value of worship, social values, cultural values, and philosophical values. 


\section{References}

Andriyanti, R., Haerudin, D., \& Kosasih, D. (2019). Tradisi Buku Taun di Desa Borogojol Kecamatan Lemahsugih-Majalengka Untuk Bahan Ajar Bahasa Sunda di SMP (Kajian Semiotik dan Etnopedagogik). Seminar Internasional Riksa Bahasa XIII. Retrieved from http://proceedings.upi.edu/index.php/riksabahasa

Arifin, A. S. P. U., \& Rahman, A. (2019). Mabbaca Doang di Pasaka Bone. Jurnal Kajian Sosial Dan Budaya, 3(2), 101-112.

Debyani, E. (2019). Sistem Simbol Dalam Upacara Adat Toraja Rambu Solo: Kajian Semiotik. Jurnal Bahasa Dan Sastra, 4(2).

Hamzah, E. I. (2021). Tradisi Mabbaca Doang Masyarakat Suku Bugis Kelurahan Kabonena Kecamatan Ulujadi Kota Palu. Moderasi: Jurnal Studi Ilmu Pengetahuan Sosial, 1(2), 25-40.

Kusuma, P. K. N., \& Nurhayati, I. K. (2017). Analisis Semiotika Roland Barthes pada Ritual Otonan di Bali. Jurnal Manajemen Komunikasi, 1(2).

Margahana, H., \& Triyanto, E. (2019). Membangun Tradisi Entrepreneurship pada Masyarakat. Jurnal Ilmah Edunomika, 03(02).

Masreng, R. (2016). Ritual Savukh Rangin: Suatu Kajian Semiotika Sosial. JURNAL TUTUR, 2.

Muhakamurrohman, A. (2014). Pesantren: Santri, Kiai, dan Tradisi. IBDA: Jurnal Kebudayaan Islam, 12.

Prayetno, N. S., \& Qomaruzzaman, B. (2021). Tradisi Peusijuek Sebagai Sarana Mediasi di Tengah Penegak Syariat Islam di Aceh. TEMALI: Jurnal Pembangunan Sosial, 4(1).

Rakhmat, P., \& Fatimah, J. M. (2016). Makna Pesan Simbolik Non Verbal Tradisi Mappadendang di Kabupaten Pinrang. Jurnal Komunikasi KAREBA, 5(2).

Rodin, R. (2013). Tradisi Tahlilan dan Yasinan. IBDA: Jurnal Kajian Islam Dan Budaya, 11(1), 7687.

Rorong, M. J. (2019). Representasi Nilai Kemanusiaan Web Series Kisah Carlo (Analisis Semiotika dalam perspektif Charles Sanders Peirce). SEMIOTIKA: Jurnal Komunikasi, 13(1). Retrieved from http://journal.ubm.ac.id/

Rusnali, N. A., \& Syam, S. (2021). The Tradition of Mappano' Lolo as Ritual Communication of the Bugis Bone Community. 2nd Annual Conference on Education and Social Science (ACCESS 2020), 99-102. Atlantis Press.

Sunjaya, T., \& Irmayanti, D. (2021). Kelas Utama Tanda Tanda Nonverbal pada Iklan PayPay. Jurnal Budaya, Bahasa Dan Sastra, 8(2), 108-126. https://doi.org/10.25139/ayumi.v8i2.4100

Susanti, A., \& Asyari, I. (2017). Nilai Pendidikan Dalam film Alangkah Lucunya Negeri Ini. MEDIAKOM, l(1).

Wekke, I. S. (2013). Islam dan Adat: Tinjauan Akulturasi Budaya dan Agama dalam Masyarakat Bugis. Analisis: Jurnal Studi Keislaman, XIII, 27-56. 